\title{
OPTIMAL TREATMENT OF PATIENTS WITH HIGH-RISK PROSTATE CANCER
}

\author{
KATARINA ANTUNAC \\ Division of Radiotherapy and Medical Oncology, University Hospital for Tumors, \\ Sestre milosrdnice University Hospital Center, Zagreb, Croatia
}

\begin{abstract}
Summary
Treatment options in subset of patients with high-risk prostate cancer are various: radical prostatectomy, hormonal therapy, radiation therapy, combined modality approach, addition of chemotherapy. Based on randomised trials data, optimal approach would consist of radical radiotherapy and long term hormonal therapy. If technically possible high dose radiotherapy, hypofractionation, image guided radiotherapy, simultaneous integrated boost on dominant intraprostatic lesion and HDR brachytherapy boost should be used as well.
\end{abstract}

KEY WORDS: high risk prostate cancer, radiotherapy, hormonal therapy, dose escalation, hypofractionation, simultaneous integrated boost

\section{OPTIMALNA TERAPIJA BOLESNIKA S RAKOM PROSTATE VISOKOG RIZIKA}

\section{Sažetak}

Kod bolesnika s rakom prostate visokog rizika postoje različite terapijske opcije: radikalna prostatektomija, hormonska terapija, zračenje, združeni pristup, dodatak kemoterapije. Prema rezultatima randomiziranih studija optimalni pristup bi bio združena primjena dugotrajne hormonske terapije i zračenja. Ukoliko tehničke mogućnosti dozvoljavaju, trebalo bi korisititi zračenje visokim dozama, hipofrakcioniranje, slikom vođenu radioterapiju, simultano integrirano povećanje doze na dominantnu intraprostatičnu leziju te primjenom brahiterapije velike brzine doze u kombinaciji s vanjskim zračenjem.

KLJUČNE RIJEČI: rak prostate visokog rizika, radioterapija, hormonska terapija, zračenje visokim dozama, hipofrakcioniranje, simultano integrirano povećanje doze

\section{INTRODUCTION}

According to European Association of Urology (EAU), high-risk prostate cancer patients are defined as those with PSA level above $20 \mathrm{ng} / \mathrm{mL}$ or Gleason score (GS) $>7$ (ISUP grade $4 / 5)$, or cT2 tumour stage (tumour involves both lobes). cT3 and cT4 and N+ stage of the disease is considered locally advanced (1). According to NCCN guidelines high-risk prostate cancer patients are those with PSA levels > $20 \mathrm{ng} / \mathrm{mL}$, or GS 4+4 (GG 4) or 4+5 (GG 5) or cT3a tumour stage (extracapsular extension). Patients with cT3b stage (tumour invades seminal vesicle(s)) and cT4 stage, primary Gleason pattern 5 and those who have tumour GS 8-10 (GG 4-5) in more than 4 cylinders are considered as very high risk prostate cancer patients (2).

Treatment options in this group of patients include radical prostatectomy with pelvic lymph node dissection, radiation with androgen depriva- 
tion therapy (external beam radiotherapy or combination of brachytherapy and external beam radiotherapy), combination of radiation, androgen deprivation therapy and chemotherapy or just androgen deprivation therapy.

Doubts in radiotherapy in this group of patients are:

- Whether to use radiotherapy or some other treatment modality

- Should some systemic treatment be used with radiotherapy, which one and for how long

- How to perform radiotherapy with regard to clinical target volume, radiation dose and fractionation.

\section{TREATMENT OPTIONS}

\section{Radical prostatectomy vs. radical radiotherapy}

Although many trials have proved superiority of radical prostatectomy compared with radical radiotherapy, even in patients with high risk prostate cancer, those trials are mainly retrospective population trials with imbalanced patients' populations comparing suboptimal treatment methods (Table 1) (3).

In general, patients that underwent radical prostatectomy were younger with less co-morbidities, had less aggressive disease, lower PSA levels and rarely had locally advanced disease. Shortly, studies were biased. Just based on these data and without randomised trials, it should not be concluded that radical prostatectomy is undoubtedly better treatment option than radical radiotherapy in this subset of patients (3). According to EAU guidelines, radical prostatectomy should be of- fered to patients with high-risk prostate cancer and life expectancy of $>10$ years only as part of multi-modal therapy (1).

\section{Radical radiotherapy}

Hormonal therapy vs. combined modality approach: hormonal therapy + radical radiotherapy

Lin and associates reported 5- year overall survival of patients diagnosed with clinically lymph node positive prostate cancer between 2014 and 2016. One group of patients was irradiated and treated with hormonal therapy, while patients in the control arm were given hormonal therapy only. Each group consisted of 314 patients. Combined modality approach resulted in $50 \%$ reduction of 5-year all cause mortality compared to hormonal therapy only. 5- year overall survival was $86 \%$ with radiotherapy and $71 \%$ without radiotherapy. Patients that were irradiated were younger, had less co-morbidities, higher PSA values and higher GS (GG) (4).

SPCG-7/SFUP-3 trial included 853 patients with locally advanced prostate cancer (cT3 in 78\% of patients) that were receiving life-long hormonal therapy: 3 months of complete androgen blockage followed by flutamide. One group of patient received radiotherapy. 10 -year cumulative incidence of prostate cancer mortality was $23.9 \%$ in group that received only hormonal therapy and $11.9 \%$ in group of patients that were also irradiated. Overall mortality cumulative incidences were $39.4 \%$ and $29.6 \%$, respectively (5).

Trial by Ward and associates included 1205 patients with high-risk prostate cancer defined as T3, T4 or T2 with PSA $>40 \mathrm{ng} / \mathrm{mL}$ or PSA $>20 \mathrm{ng} /$

Table 1

TRIALS COMPARING RADICAL PROSTATECTOMY WITH RADICAL RADIOTHERAPY IN HIGH-RISK PROSTATE CANCER (3)

\begin{tabular}{|l|l|l|l|l|}
\hline Trial & $\begin{array}{l}\text { Number } \\
\text { of patients }\end{array}$ & Population & Follow up & $\begin{array}{l}\text { Outcome: } \\
\text { RP better than RT }\end{array}$ \\
\hline Cooperberg et al. Cancer 2010 & 7539 & CaPSURE register, USA & 4,2 years & Yes \\
\hline Hoffman et al. JNCI 2013. & 1500 & Prostate Cancer Outcome Study, USA & 15 years & Yes \\
\hline Abdollah et al. Eur Urol 2011. & 404604 & SEER database, USA & 5 years & Yes \\
\hline Sun et al. BJU Int 2014. & 67087 & SEER Medicare linked database, USA & 10 years & Yes \\
\hline Zelefsky et al. J Clin Oncol 2010 & 2300 & Institutional register, USA & 8 years & Yes \\
\hline Nepple et al. Eur Urol 2014. & 6000 & 2 tertiary centres & 7,2 years & Yes \\
\hline Abdollah et al. Int J Urol 2012. & 68665 & SEER Medicare linked database, USA & unknown & Yes \\
\hline Sooriakumaran et al. BMJ 2014 & 34500 & PcBaSe, Sweden & 5,3 years & Yes \\
\hline Boorijan et al. Cancer 2011 & 1800 & 2 tertiary centres & 10,2 years & yes \\
\hline
\end{tabular}


mL with GS 8 (GG 4) or higher in period 19952005. 602 patients were given only hormonal therapy (surgical castration or LHRH agonist) and 603 patients were also irradiated. Dose on prostate and seminal vesicles was $65-69$ Gy and dose on pelvic lymph nodes $45 \mathrm{~Gy}$. Irradiated patients had better 7- year overall survival: $74 \%$ vs. $66 \%$ (6).

All these results indicate undoubted advantage of combined modality approach. Hormonal therapy as a sole treatment modality should be an option just for patients in whom irradiation would be contraindicated.

\section{Radiotherapy vs. combined modality approach:} hormonal therapy + radical radiotherapy

Meta- analysis by Bria published in 2009 included 7 trials and showed benefit of addition of hormonal therapy to radiotherapy with regard to lower rate of biochemical relapse $(10 \%$ absolute difference). Patients receiving hormonal therapy had better clinical progression free survival (absolute difference $7.7 \%)$, overall survival $(4.9 \%)$, tumour specific survival (5.5\%) and less local and distant relapse (difference $36 \%$ and $27 \%$, respectively) without significant difference in toxicity between two treatments (7).

However, it is not clear for how long should patients with high-risk prostate cancer receive hormonal therapy when combined with high dose radiotherapy.

Phase 3 randomised trial included 362 patients with intermediate and high risk prostate cancer. Median dose on prostate was 78 Gy. All patients received neoadjuvant and concomitant hormonal therapy; patients in experimental arm continued with goserelin for up to two years. After 5 years of follow up patients on long term hormonal therapy had statistically significant better biochemical free survival, overall survival and metastases free survival ( 86 vs. $95 \%, 89$ vs. $94 \%$ and 85 vs. $93 \%$, respectively). No significant difference in acute and late toxicity was observed between groups (8). In conclusion, benefit of longterm hormonal treatment still exists, regardless of higher radiation dose applied on prostate.

Combined modality approach, meaning radiotherapy with hormonal therapy in patients with high- risk prostate cancer is significantly better option than either of these two modalities alone.

\section{Neoadjuvant chemotherapy with radiotherapy}

GETUG 12 trial included 413 patients with high- risk prostate cancer that were receiving goserelin for 3 years and had local treatment, which in $87 \%$ of patients was radiotherapy (doses 74 $78 \mathrm{~Gy}$ ). Patients randomised in experimental arm of the trial were given 4 cycles of docetaxel with estramustine prior to beginning of radiotherapy. PSA response, defined as PSA level $<0.2 \mathrm{ng} / \mathrm{mL}$ after 3 months of treatment, was achieved in $34 \%$ patients in experimental arm and in $15 \%$ of patients in control arm. After 4.6 years of follow up 4- year progression free survival rates were $85 \%$ in patients who received docetaxel/estramustine and $81 \%$ in control group ( $p=0.26) .27 \%$ of patients receiving chemotherapy experienced neutropenia grade 3-4; rate of febrile neutropenia was $2 \%$ (9).

\section{Whole pelvis irradiation}

It is still unclear whether to include pelvic lymph nodes in target volume in this subset of patients.

When setting up an indication either Roach formula $(\mathrm{N}+=2 / 3$ PSA $+(\mathrm{GS}-6) \times 10)$ or nomograms are being used (10). In case the risk of lymph node involvement is $>15 \%$, whole pelvis radiotherapy is indicated. Clinically positive lymph nodes on MRI or CT scan are those larger than 10 $\mathrm{mm}$ in shorter diameter or larger than $8 \mathrm{~mm}$, if lymph node is round. Choline PET scan has no role in lymph nodes involvement evaluation due to its low specificity (1).

Retrospective analysis of RECAP basis data involved 670 high-risk prostate cancer patients irradiated between 1993 -1999. 234 patients had just prostate irradiation- PORT (doses 55- 82.4 Gy, median $72 \mathrm{~Gy}$ ) and 436 patients had also pelvic lymph node irradiation- WPRT (36- 56Gy, median 46 Gy). After median follow up of 77 (WPRT) and 86 months (PORT), there was no statistically significant difference between those two groups regarding 5 and 10- year biochemical failure, disease free survival, overall survival or cancer specific survival. In WPRT group early gastrointestinal and late genitourinary toxicity was more frequently observed (11).

\section{High dose radiotherapy}

A number of trials evaluated high dose radiotherapy in patients with localised prostate can- 
Lib Oncol. 2018;46(2-3):88-94

Table 2

DOSE ESCALATION RANDOMISED TRIALS IN LOCALISED PROSTATE CANCER (1)

\begin{tabular}{|c|c|c|c|c|c|c|}
\hline Trial & $\begin{array}{l}\text { No of } \\
\text { patients }\end{array}$ & Stage & $\begin{array}{l}\text { Radiation } \\
\text { dose }\end{array}$ & Follow-up & Outcome & Results \\
\hline $\begin{array}{l}\text { MD Anderson } \\
\text { Kuban et al. } \\
\text { Int J Radiat Oncol } \\
\text { Biol Phys, } 2011\end{array}$ & 301 & $\begin{array}{l}\text { T1-3, N0, M0, } \\
\text { PSA } 10 \mathrm{ng} / \mathrm{mL} \text { vs } \\
\text { PSA }>10 \mathrm{ng} / \mathrm{mL}\end{array}$ & 70 vs $78 \mathrm{~Gy}$ & $\begin{array}{l}\text { median } \\
9 \text { years }\end{array}$ & $\begin{array}{l}\text { disease specific } \\
\text { mortality (DSM) } \\
\text { vs other cause } \\
\text { of death }\end{array}$ & $\begin{array}{l}\text { high risk: (PSA> 10): } \\
\text { DSM 16\% 70Gy, 4\% 78Gy } \\
(p=0,05) \\
\text { higher risk DSM 15\% 70Gy, } \\
2 \% 78 G y(p=0,03)\end{array}$ \\
\hline $\begin{array}{l}\text { PROG 95-09 } \\
\text { Zietman et al. } \\
\text { J Clin Oncol } 2010\end{array}$ & 393 & $\begin{array}{l}\text { T1b-2b } \\
\text { PSA 15ng/mL } \\
75 \% \text { GS }<6\end{array}$ & $\begin{array}{l}70,2 \text { vs } 79,2 \\
\text { Gy, proton } \\
\text { boost } 19,8 \\
\text { vs } 28,8 \mathrm{~Gy}\end{array}$ & $\begin{array}{l}\text { median } \\
8,9 \text { years }\end{array}$ & $\begin{array}{l}\text { 10- year ASTRO } \\
\text { biochemical failure } \\
\text { (BCF) }\end{array}$ & $\begin{array}{l}\text { all patients: BF } 32 \% 70,2 \mathrm{~Gy} \text {, } \\
17 \% 79,2 \text { Gy }(p<0,0001) \\
\text { low risk: BF } 28 \% 70,2 \mathrm{~Gy} \text {, } \\
7 \% 79,2 \text { Gy }(p<0,0001)\end{array}$ \\
\hline $\begin{array}{l}\text { MRC RT01 } \\
\text { Dearneley et al. } \\
\text { Lancet Oncol } 2014\end{array}$ & 843 & $\begin{array}{l}\text { T1b-T3a NOM0, } \\
\text { PSA }<50 \mathrm{ng} / \mathrm{mL} \\
\text { neoadj. HT }\end{array}$ & 64 vs $74 G y$ & $\begin{array}{l}\text { median } \\
10 \text { years }\end{array}$ & $\begin{array}{l}\text { biochemical } \\
\text { progression free } \\
\text { survival (BFS), } \\
\text { overall survival (OS) }\end{array}$ & $\begin{array}{l}\text { BFS } 43 \% 64 G y, 55 \% 74 G y \\
(p=0,0003) \\
\text { OS } 71 \% \text { both groups } \\
(p=0,96)\end{array}$ \\
\hline $\begin{array}{l}\text { Dutch trial } \\
\text { Heemsbergen et al. } \\
\text { Radiother Oncol } \\
2014\end{array}$ & 664 & $\begin{array}{l}\text { T1b-T4 } \\
164 \text { patients with } \\
\text { neoadjuvant HT }\end{array}$ & 68 vs $78 \mathrm{~Gy}$ & $\begin{array}{l}\text { median } \\
110 \text { months }\end{array}$ & $\begin{array}{l}\text { biochemical } \\
\text { (Phoenix definition) } \\
\text { and clinical failure } \\
\text { free (FFF) }\end{array}$ & $\begin{array}{l}\text { FFF 43\% 68Gy, 49\% } 78 \text { Gy } \\
(p=0,045)\end{array}$ \\
\hline $\begin{array}{l}\text { GETUG } 06 \\
\text { Beckendorf et al. } \\
\text { Int J Radiat Oncol } \\
\text { Biol Phys } 2011\end{array}$ & 306 & $\begin{array}{l}\text { T1b-3a, N0, M0, } \\
\text { PSA<50ng/mL }\end{array}$ & 70 vs $80 \mathrm{~Gy}$ & $\begin{array}{l}\text { median } \\
61 \text { month }\end{array}$ & $\begin{array}{l}\text { ASTRO biochemical } \\
\text { failure (BCF) }\end{array}$ & BF 39\% 70Gy, 28\% 80Gy \\
\hline $\begin{array}{l}\text { retrospective } \\
\text { NCDB trial } \\
\text { Kabasi et al, } \\
\text { JAMA Oncol } 2015\end{array}$ & $\begin{array}{l}16714 \\
13538\end{array}$ & $\begin{array}{l}\text { intermediate risk, } \\
49 \% \mathrm{HT} \\
\text { high risk, } 77 \% \mathrm{HT}\end{array}$ & $\begin{array}{l}<75,6 \text { vs } \\
>75,6 \text { Gy }\end{array}$ & $\begin{array}{l}\text { median } \\
85-86 \\
\text { months }\end{array}$ & overall survival (OS) & $\begin{array}{l}\text { HR } 0,84 \text { for dose escalation } \\
(p<0,001) \\
\text { HR } 0,82 \text { for dose escalation } \\
(p<0,001)\end{array}$ \\
\hline
\end{tabular}

cer, regardless of the disease stage. Better 5- year biochemical free survival was observed. Trials are summarised on Table 2 (1).

Retrospective NCDB trial has analysed 42 481 patients' data: 12229 low risk, 16714 intermediate risk and 13538 high risk prostate cancer patients irradiated between 2004 - 2006. They were divided into two groups regarding radiation dose: standard dose - 68.4- 75.6 Gy and escalated dose - 75.6- 90 Gy. In groups of patients with intermediate and high risk prostate cancer, better overall survival was observed with dose escalation (HR 0.84 and 0.82 , $\mathrm{p}<0.001$ ). No benefit of dose escalation has been shown in group of patients with low risk prostate cancer $(\mathrm{HR} 0.98, \mathrm{p}=0.54)$. For every 2 Gy dose increment there was $7.8 \%$ reduction of death risk in intermediate risk patients and 6.3\% reduction of death risk in high risk patients (12).

\section{Integrated boost on macroscopic lesion in prostate}

Dose escalation leads to better outcome in patients with high risk prostate cancer, but further increment is limited by surrounding tissue tolerance. Since prostate cancer relapses occur in area where macroscopic tumour is located - dominant intraprostatic lesion (DIL), it is reasonable to apply higher dose on that exact part of prostate using simultaneous integrated boost (SIB).

FLAME trial included 541 patients with prostate cancer, $84 \%$ of which had high risk cancer. In experimental arm (284 pts) dose of $77 \mathrm{~Gy}$ in 35 fractions to the entire prostate gland was administered with an integrated boost up to 95 Gy to the macroscopic lesion. Control arm received 77Gy in 35 fractions to the entire prostate only. After median follow up of 22 months data regarding disease control were still lacking, but data regarding toxicity were published. No significant difference was found between both treatment arms for genitourinary toxicity. Urinary symptoms related to quality of life were not significantly different across treatment arms (13).

Phase 3 trial by Sundahl included 410 patients with T1-4N0M0 prostate cancer; $48 \%$ of them had high risk prostate cancer. Prescribed dose on prostate was 78Gy in 38 fractions; patients that had visible dominant intraprostatic lesion on MRI were given 82 Gy in 38 fractions on that par- 
Lib Oncol. 2018;46(2-3):88-94

Table 3

PHASE 3 TRIALS - HYPOFRACTIONATION IN PRIMARY RADIOTHERAPY OF PROSTATE CANCER (1)

\begin{tabular}{|c|c|c|c|c|c|c|c|}
\hline Trial & $\begin{array}{l}\text { No of } \\
\text { patients }\end{array}$ & Risk factors & $\begin{array}{l}\text { Radiation } \\
\text { regimen }\end{array}$ & BED & $\begin{array}{l}\text { Median } \\
\text { follow up }\end{array}$ & Outcome & Toxicity \\
\hline $\begin{array}{l}\text { Lukka et al. } \\
\text { J Clin Oncol } 2005\end{array}$ & $\begin{array}{l}466 \\
470\end{array}$ & $\begin{array}{l}60 \% \text { GS6 } \\
31 \% \text { GS7 } \\
9 \% \text { GS } 8-10\end{array}$ & $\begin{array}{l}52,5 \mathrm{~Gy} / 20 \\
66 \mathrm{~Gy} / 33\end{array}$ & $\begin{array}{l}62 \mathrm{~Gy} \\
66 \mathrm{~Gy}\end{array}$ & 68 months & $\begin{array}{l}\text { 5- year free from } \\
\text { biochemical failure } \\
\text { (FFBF) } \\
40 \text { vs } 43 \% \text { (NS) }\end{array}$ & $\begin{array}{l}\text { Gr3 } \\
2 \text { vs } 1 \% \text { (NS) }\end{array}$ \\
\hline $\begin{array}{l}\text { Arcangeli et al. } \\
\text { Int J Radiat Oncol } \\
\text { Biol Phys } 2010\end{array}$ & $\begin{array}{l}83 \\
85\end{array}$ & $\begin{array}{l}26 \% \text { GS } 7 \\
74 \% \text { GS }>7\end{array}$ & $\begin{array}{l}62 \mathrm{~Gy} / 20 \\
80 \mathrm{~Gy} / 40\end{array}$ & $\begin{array}{l}81,4 \mathrm{~Gy} \\
80 \mathrm{~Gy}\end{array}$ & 70 months & $\begin{array}{l}\text { 5- year FFBF } 85 \\
\text { vs } 79 \% \text { (NS), } \\
\text { statistically } \\
\text { significant } \\
\text { for GS> } 4+3\end{array}$ & $\begin{array}{l}3 \text { - years Gr2 and higher } \\
\text { GU } 16 \text { vs } 11 \% \text { (NS) } \\
\text { GI } 17 \text { vs } 14 \% \text { (NS) }\end{array}$ \\
\hline $\begin{array}{l}\text { Pollack et al } \\
\text { J Clin Oncol } 2013\end{array}$ & $\begin{array}{l}151 \\
152\end{array}$ & $\begin{array}{l}34 \% \text { GS } 6 \\
47 \% \text { GS } 7 \\
19 \% \text { GS } 8-10\end{array}$ & $\begin{array}{l}70,2 \mathrm{~Gy} / 26 \\
78 \mathrm{~Gy} / 36\end{array}$ & $\begin{array}{l}84 \mathrm{~Gy} \\
78 \mathrm{~Gy}\end{array}$ & 68 months & $\begin{array}{l}\text { 5- year biochemical } \\
\text { or clinical disease } \\
\text { free (BCDF) } \\
23 \text { vs } 21 \%(N S)\end{array}$ & $\begin{array}{l}\text { 5- year Gr2 and higher } \\
\text { GU } 13 \text { vs } 13 \%(N S) \\
\text { Gl } 9 \text { vs } 9 \%(N S)\end{array}$ \\
\hline $\begin{array}{l}\text { Aluwini et al } \\
\text { Lancet } 2015\end{array}$ & $\begin{array}{l}403 \\
391\end{array}$ & $\begin{array}{l}30 \% \text { GS } 6 \\
\text { and less } \\
45 \% \text { GS } 7 \\
25 \% \text { GS } 8-10\end{array}$ & $\begin{array}{l}\text { 64,6Gy/19 } \\
78 \mathrm{~Gy} / 39\end{array}$ & $\begin{array}{l}90,4 \mathrm{~Gy} \\
78 \mathrm{~Gy}\end{array}$ & 49 months & no data & $\begin{array}{l}3 \text { - months } \mathrm{Gr} 2 \text { and higher } \\
\text { GU } 23 \text { vs } 22 \% \text { (NS) } \\
\text { GI } 13 \text { vs } 13 \% \text { (NS) }\end{array}$ \\
\hline
\end{tabular}

ticular area (SIB; dose equivalent $86 \mathrm{~Gy}$ for $\alpha / \beta 1.5$ ) or more, if tolerated by surrounding tissues. No difference between groups was observed in $6-$ year risk for development of late grade 2 and 3 genitourinary or bowel toxicity. After 36, 42, 72 and 96 months of follow up, in group of patients that received SIB higher frequency of urinary incontinence was noticed (14).

\section{Hypofractionation}

Hypofractionation stands for irradiation in daily fractions higher than $2 \mathrm{~Gy}$. It is assumed that $\alpha / \beta$ ratio of prostate cancer is about 1.5 , which makes it sensitive on fraction size. Besides expected clinical benefit, hypofractionation lowers number of radiation sessions, which shortens overall treatment time. If doses higher than $4 \mathrm{~Gy}$ per fraction are to be applied, it is necessary to use image guided radiotherapy (IGRT) or stereotactic irradiation. In published trials short biochemical disease control is similar between treatment arms but long term effects on organs at risk (bladder and bowel) are not yet completely known, bearing in mind short follow up. Phase 3 trials are summarized on Table 3 (1).

In phase 3 CHHip trial 3216 patients with prostate cancer T1b-T3aN0M0 were randomised in 3 groups with regard to radiation regimen: 74 Gy in 37 fractions, 60 Gy in 20 fractions and 57 Gy in 19 fractions. IMRT and SIB were used. WPRT was not performed. 97\% of patients received neoadjuvant and concomitant hormonal therapy. In each group $12 \%$ of patients had high risk prostate cancer. IGRT was not used in $53 \%$ of patients in each group. After median follow up of 64 months the proportion of patients who were biochemical or clinical failure free at 5 years was 88.3 for $74 \mathrm{~Gy}$, $90.6 \%$ for $60 \mathrm{~Gy} / 20$ and $85.9 \%$ for $57 \mathrm{~Gy} / 19.60 \mathrm{~Gy}$ was non- inferior to $74 \mathrm{~Gy}$, but non- inferiority could not be claimed for $57 \mathrm{~Gy} / 19$ compared with 74 Gy. No significant difference between treatment groups was observed for late toxicity: frequencies of grade 2 and higher bowel and bladder adverse reactions were $13.7 \%$ and $9.1 \%$ respectively for $74 \mathrm{~Gy}, 11.9 \%$ and $11.7 \%$ for $60 \mathrm{~Gy} / 20$ and $11.3 \%$ and $6.6 \%$ for $57 \mathrm{~Gy} / 19$ (15).

HYPRO trial enrolled 820 patients with intermediate-risk to high-risk T1b-T4NX-N0MX-M0 localised prostate cancer with a PSA of $60 \mu \mathrm{g} / \mathrm{L}$ or less. They were randomly assigned (1:1) to either hypofractionated radiotherapy of 64.6 Gy (19 fractions of $3.4 \mathrm{~Gy}$, three fractions per week) or conventionally fractionated radiotherapy of 78 Gy (39 fractions of $2 \mathrm{~Gy}$, five fractions per week). Based on an estimated $\alpha / \beta$ ratio for prostate cancer of 1.5 $\mathrm{Gy}$, the equivalent total dose in fractions of $2 \mathrm{~Gy}$ was $90.4 \mathrm{~Gy}$ for hypofractionation, compared with 78 Gy for conventional fractionation. $67 \%$ of patients received concomitant androgen deprivation therapy (median duration 32 months). The primary endpoint was relapse-free survival. After me- 
dian follow-up of 60 months, 5-year relapse-free survival was $80.5 \%$ for patients assigned hypofractionation and $77.1 \%$ for those allocated conventional fractionation. 3 months after radiotherapy, no difference in frequency of grade 2 or worse genitourinary or gastrointestinal toxicity was observed between treatment groups. However, the cumulative incidence of grade 2 or worse acute gastrointestinal toxicity by 120 days after radiotherapy was higher in patients given hypofractionation: $42 \%$ vs. $31.2 \%$ in the standard fractionation group. There were no treatment-related deaths $(16,17)$.

NCI Canada trial randomized 936 patients with cT1-T2 prostate cancer whose PSA levels were $<40 \mu \mathrm{g} / \mathrm{L}$ to either hypofractionated radiotherapy of $52.5 \mathrm{~Gy}$ (2.62 Gy per fraction) or conventionally fractionated radiotherapy of $66 \mathrm{~Gy}$ (33 fractions of $2 \mathrm{~Gy}$ ). $20 \%$ of patients in each treatment arm had PSA level $15 \mu \mathrm{g} / \mathrm{L}$ or higher, therefore could be defined as high- risk patients. The primary outcome was biochemical or clinical failure (BCF). Median follow up was 5.7 years. At 5 years, the BCF probability was $52.95 \%$ in the long arm and $59.95 \%$ in the short arm, favouring the long arm. No difference in 2-year postradiotherapy biopsy or in overall survival was detected between the arms. Acute toxicity was higher in the short arm $(11.4 \%)$ compared with the long arm (7\%). However, late toxicity was similarly low in both arms (3.2\%). It is to be noticed that patients did not receive concomitant androgen deprivation therapy and that prescribed doses were much lower than those prescribed nowadays. (18).

\section{HDR brachytherapy as boost}

In patients with high-risk prostate cancer high dose rate (HDR) brachytherapy could be used as a dose escalating boost delivered in combination with external beam radiotherapy. Iridium-192 (IR-192) isotope is being introduced through implanted needles or catheters. Radiation dose is delivered in minutes, implantation is temporary and there are no radiation protection issues for patient or carers. Patients with significant urinary outflow symptoms are not candidates for HDR boost $(19,1)$.

A randomised phase-III trial compared external beam radiotherapy (EBRT) alone with EBRT combined with high-dose-rate brachytherapy boost
(HDR-BTb) in 218 patients with localised prostate adenocarcinoma. About $50 \%$ of patients in each arm had high- risk prostate cancer. Patients in EBRT arm received a total dose of $55 \mathrm{~Gy}$ in 20 daily fractions while patients in HDR-BTb arm received EBRT 35.75 Gy in 13 fractions followed by HDR-BT boost of 2x 8.5 Gy in $24 \mathrm{~h}$. Biochemical/ clinical relapse-free survival (RFS) was the primary endpoint. Secondary endpoints were overall survival (OS), urinary and bowel toxicity. After 4 years median time to relapse was 116 months in EBRT + HDR-BTb group, compared to 74 months in EBRT only group. (log rank $p=0.04)$. In multivariate analysis treatment arm, risk category and ADT were significant covariates for risk of relapse. Differences in OS were not significant. Incidence of severe late urinary and bowel morbidity was similar: the 5 and 7 year incidence for patients with any severe urinary symptom was $26 \%$ and $31 \%$ for those treated with EBRT + HDR-BTb compared with $26 \%$ and $30 \%$ for patients in EBRT only arm $(\log$ rank $p=0.5)$. The incidence of severe bowel events was $7 \%$ and $6 \%$, respectively, at 5 and 7 years; $(\log$ rank $p=0.8)(20)$.

\section{CONCLUSION}

According to literature, recommended therapy for high risk prostate cancer patients would be high dose radical radiotherapy with long term hormonal therapy. Depending on each centre experience as well as technical possibilities, use of simultaneous integrated boost, brachytherapy HDR boost or hypofractionation should be taken into consideration.

\section{LITERATURE:}

1. EAU Guidelines. Edn. presented at the EAU Annual Congress Copenhagen 2018. ISBN 978-94-92671-01-1.

2. Prostate cancer NCCN Guidelines Version 2.2018. (updated 08 March 2018; cited 03 May 2018) Available from https://www.nccn.org/professionals/physician_ gls/pdf/prostate.pdf

3. Briganti A. Surgery or radiotherapy for prostate cancer: what are we talking about? Global Congress on Prostate Cancer 2015.

4. Lin CC, Gray P J, Ahmedin J, Efstathiou J A. Androgen deprivation with or without radiation therapy for clinically node-positive prostate cancer. J Natl Cancer Inst. 2015;107(7):pii: djv119. doi: 10.1093/jnci/djv119. 
5. Widmark A, Klepp O, Solberg A, Damber J, Angelsen A, Fransson $P$ et al. Endocrine treatment, with or without radiotherapy, in locally advanced prostate cancer (SPCG-7/SFUO-3): an open randomised phase III trial. Lancet. 2009;373:301-08.

6. Warde P, Mason M, Ding K, Kirkbride P, Brundage M, Cowan $\mathrm{R}$ et al. Combined androgen deprivation therapy and radiation therapy for locally advanced prostate cancer, a randomised phase 3 trial. Lancet. 2011; 378:2104-11.

7. Bria E, Cuppone F, Gianarelli D, Millela M, Ruggeri E M, Sperduti I et al. Does hormone treatment added to radiotherapy improve outcome in locally advanced prostate cancer? Cancer. 2009;115:3446-3456.

8. Zapatero A, Guerrero A, Maldonado J, Alvarez A, Gonzales San Segundo C, Cabeza Rodrigues M et al. Randomised phase III trial of adjuvant androgen deprivation in combination with high dose conformal radiotherapy in intermediate and high risk localised prostate cancer. Int J Radiat Oncol Biol Phys. 2014;90 (1S):S1(abs:PL-02).

9. Fizazi K, Lesaunier F, Delva R, Gravis G, Rolland F, Priou $\mathrm{F}$ et al. A phase III trial of docetaxel- estramustine in high-risk localised prostate cancer: a planned analysis of response, toxicity and quality of life in the GETUG 12 trial. EJC. 2012;48:209-217.

10. Roach M, Marquez C, Yuo H S, Naravan P, Coleman L, Nseyo U O. Predicting the risk od lymph node involvement using the pre-treatment prostate specific antigen and Gleason score in men with clinically localised prostate cancer. Int J Radiat Oncol Biol Phys. 1994;28(1):33-7.

11. Torrecilla J L, Munoz Garcia J L, Jove i Teixido J, Hervas Moron A, Casana Giner M, Mengual Cloquell J L et al. Influence of whole pelvis radiotherapy in high risk PC outcomes treated with radical intention. RECAP data base. Radiother Oncol. 2014;111(Suppl1): 290-1(abs P0-0728).

12. Kalbasi A, Li J, Berman A T, Swisher-McClure S, Smaldone M, Uzzo R G et al. Dose-escalated irradiation and overall survival in men with non-metastatic prostate cancer. JAMA Oncol. 2015;1(7):897-906.

13. Van Loon V, Van Vulpen M, Pos F, Haustermans K, Smoonk R, Van den Bergh L. FLAME: influence of dose escalation to $95 \mathrm{~Gy}$ for prostate cancer on urethra-related toxicity and QOL. Radiother Oncol. 2016;119(Suppl 1):S130-1(absOC-0282).

14. Sundahl N. De Meerleer G, Villeirs G, Ost P, De Neve W, Nicolaas L et al. Combining high dose external beam radiotherapy with a simultaneous integrated boost to the dominant intraprostatic lesion: analysis of genito-urinary and rectal toxicity. Radiother Oncol. 2016;119:398-404.

15. Dearnaley D, Syndikus I, Mossop H, Khoo V, Birtle A, Bloomfield D et al. Conventional versus hypofractionated high-dose intensity-modulated radiotherapy for prostate cancer: 5-year outcomes of the randomised, non-inferiority, phase 3 CHHip trial. Lancet Oncol. 2016;17:1047-60.

16. Aluwini S, Pos F, Schimmel E, van Lin E, Krol S, van der Toorn PP, de Jager H, Dirkx M, Alemayehu WG, Heijmen B and Incrocci L. Hypofractionated versus conventionally fractionated radiotherapy for patients with prostate cancer (HYPRO): acute toxicity results from a randomised non-inferiority phase 3 trial. Lancet Oncol. 2015;16(3):274-83.

17. Incrocci L, Wortel RC, Alemayehu WG, Aluwini S, Schimmel E, Krol S, van der Toorn PP, Jager H, Heemsbergen W, Heijmen B, Pos F. Hypofractionated versus conventionally fractionated radiotherapy for patients with localised prostate cancer (HYPRO): final efficacy results from a randomised, multicentre, openlabel, phase 3 trial. Lancet Oncol. 2016;17(8):1061-1069.

18. Lukka H, Hayter C, Julian JA, Warde P, Morris WJ, Gospodarowicz M, Levine M, Sathya J, Choo R, Prichard $\mathrm{H}$, Brundage M, Kwan W. Randomized trial comparing two fractionation schedules for patients with localized prostate cancer.JClin Oncol.2005;23(25):61328.

19. Hoskin PJ, Colombo A, Henry A, Niehoff P, Paulsen Hellebust T, Siebert FA, Kovacs G. GEC/ESTRO recommendations on high dose rate afterloading brachytherapy for localised prostate cancer: an update. Radiother Oncol. 2013;107(3):325-32

20. Hoskin PJ, Rojas AM, Bownes PJ, Lowe GJ, Ostler PJ, Bryant L. Randomised trial of external beam radiotherapy alone or combined with high-dose-rate brachytherapy boost for localised prostate cancer. Radiother Oncol 2012;103(2):217-22.

Corresponding author: Katarina Antunac, Division of Radiotherapy and Medical Oncology, University Hospital for Tumors, Sestre milosrdnice University Hospital Center, Ilica 197, 10000 Zagreb, Croatia. e-mail: katarina.antunac@zg.htnet.hr 